\title{
Analysis of Tourism Development: A Case of the Beach Tourism in Buton Tengah, Southeast Sulawesi Province
}

\section{Ahmad Zulkivar La} Bonto

Faculty of Economics and Business, Universitas Brawijaya, Indonesia zulkivar@gmail.com

\section{Rofiati}

Faculty of Economics and Business, Universitas Brawijaya, Indonesia

\section{Christin Susilowati}

Faculty of Economics and

Business, Universitas

Brawijaya, Indonesia

\begin{abstract}
This study analyzes the development of beach tourism in Buton Tengah, namely, Mutiara beach in Gumanano Village, Wantopi Beach in Wantopi Village, and Katembe Beach in Madongka Village. This study involved stakeholders of beach tourism in Buton Tengah as informants. They are representatives from the Tourism Department, Assembly at Buton Tengah regional, Village Heads, Communities and tourists of each tourist destination. This research is a type of qualitative research with a case study approach, and also data collection using direct interviews to the informant. The result of this study shows that the first, beach tourism in Buton Tengah is a type of natural tourism that have unique difference between one type of tour with another tour, in addition, there are also cultural and artificial tours. Second, beach tourism in Buton Tengah is currently managed by the local government and the local village government. Third, there is a miscommunication between stakeholders which causes the development of beach tourism in Buton Tengah to be less developed and lack competitive. Fourth, the lack of competitiveness strategies implemented by stakeholders. The last, the lack of stakeholders' knowledge regarding the development of competitive beach tourism..
\end{abstract}

KEYWORDS: Strategy, Tourism Development, Buton Tengah

Received November 2019 | Accepted March 2020 | Available online April 2020

DOI: http://dx.doi.org 10.18860/mec-j.v4i1.7995

\section{INTRODUCTION}

Antariksa(2017) community activities around tourism will give benefits to the welfare of the community itself. Chin et al.(2017) this is because tourism has benefits for the economic growth of a region and the creation of new jobs. In addition, tourism also gives benefits to the country that can be seen from the amount of foreign exchange earnings, where the foreign exchange comes from foreign tourists who come in Indonesia for traveling purpose. According to Oskaria(2016), the tourism sector in Indonesia in 2016 contributed US $\$ 13,568$ billion, and in 2017 US $\$ 16.8$ billion to Indonesia's foreign exchange, and in 2018 it is estimated that by the end of December it would be US $\$ 20$ billion. The more foreign tourists visiting Indonesia, of course the greater foreign exchange income also. 
Jokowi, (2018) Indonesia has 714 ethnic groups and more than 1,100 diverse regional languages. In Indonesia, regions that use culture as a tourist attraction, for example, cultural tourism in Bali and Toraja. (Hieu and Rasovska, 2017) state that cultural tourism is an activity related to museum visits, artistic activities, cultural heritage zones, lifestyles formed by faith, language, religion, cooking and nutrition, clothing style, buildings, etc. In addition to natural and cultural conditions, Indonesia currently also has an interesting culinary tour. According to (Astuti, 2017) there are around 5350 different food recipes in Indonesia. Arif on CNN added that 5 (five) of them Soto, Gado-Gado, Fried Rice, Rendang, and Sate were promoted as Indonesian culinary icons, two of which were categorized as the most delicious food in the world, namely Rendang and Fried Rice. (Hieu and Rasovska, 2017) one of the cultural tourism is cooking.

The current government, realizing the importance of the tourism sector and potential that is increasingly vital, began to give more attention to the development of tourism. This condition is proven by the increasing data of foreign tourists visiting Indonesia. According to (CNN Indonesia, 2017), the number of foreign tourist arrivals to Indonesia was 14.03 million visits, an increase of $21.88 \%$ from the previous year which was 11.51 million visits. (Chin et al. 2017) The increasing number of visits illustrates developments in tourism.

Leong and Jacky (2011) argue that the encouragement to develop tourism is caused by human desires (tourists). This situation will encourage the government and the community to make improvements and innovations to the resources they have and turn them into interesting objects that can be visited by tourists. According to Antariksa(2016) the number of tourist destinations offered by several regions in Indonesia will encourage the community, intellectuals, and the government and NGOs to always conduct the research, development, and control of the potential of tourism place. So that it will create competition between tourism managers to look for ways how to improve and differentiate their types of promotions (Sotiriadis, 2014).

Toader et al. (2013), the development of tourism products must be based on consumer demands. Consumers with high incomes and relatively good living, they will demand more individual products. This condition will be used by producers (stakeholders) tourism to improve and develop tourism in accordance with more complex market demands. Chin et al.(2017) these stakeholders have an awareness of the competitiveness of tourism. They will carry out development based on tourism destinations, thus creating a competitive advantage.

Crosby (1991) stakeholders are grouped broadly into 3 namely: (1) primary stakeholders, (2) secondary stakeholders, and (3) key stakeholders. They are individuals or groups involved, and/or affected either positively or negatively in an activity.

Zibert et al. (2017) explain some of the roles of stakeholders in tourism development, such as the public/government sector paying attention to long-term social and economic interests and emphasizing the development of tourism, the private sector operates at long-term and short-term estimates, and civil society are expected to improve the quality of life in tourism, all are involved and work together in achieving personal goals. 
The role of these stakeholders, of course, will increase the success of tourism in winning the current competition.

According to Tazbir (2012), nowadays, competition of tourism among regions in Indonesia is increasingly competitive "To be able to survive it requires effective promotion and marketing". Tourism places that have high competitiveness in Indonesia such as beaches in Bali, dive sites in Bunaken, Rinjani mountain in Lombok, National Parks in Sumatra, etc. The success of these tours will certainly be a trigger for the development of other tourism in all regions in Indonesia.

Antariksa (2016) revealed that the development of good tourism is very dependent on good policies. (Crosby 1991) in establishing a policy should be based on interests and whose concerns (other stakeholders). (Kammi, 1999) illustrates that a policy to be taken always involves some other stakeholders to get support, and more effective interactions, so that it will increase support for the implementation of policy. Among the tourism areas that are currently being developed, some areas are successful in tourism but have not been maximally managed, for example, one of the tourist areas in Southeast Sulawesi Province, Wakatobi, which offers underwater attractions.

According to Hugua(2016) Wakatobi is a type of tourism that does not offer a lot of natural attractions, so it is necessary to cooperate with the tours of the nearest area, and one of them is Buton Regency. Buton Regency has tourism potential such as Lambusango Forest Tourism, Cultural Tourism of the Old City, and the widest Fortress in the World, and others.

Apart from the Buton Regency, an area that has great potential in the tourism sector is Buton Tengah Regency. Buton Tengah Regency is one of the new autonomous region which was expanded from Buton Regency in 2014, which is known as Negri 1000 gua. (Suara.com, 2016) Buton Tengah has the potential of attractions that are ready to be developed and published. This is supported by Lukman as head of the Department of Tourism and Economy of Buton Tengah Regency stated that "Buton Tengah tourism has great potential, from marine tourism, cultural tourism, and adventure tourism" (sultra.antarnews, 2017). It means that Buton Tengah currently has tourism potential that is ready to develop.

Central Buton has tourism potential including natural and cultural tourism. Natural attractions such as Mutiara Beach, Katembe Beach, Gubari Beach, Wantopi Beach, Labobo Beach, etc. Not only beaches, Buton Tengah also has cave and bay tours (www.baubaupos.com, 2015) including Loba-Loba caves, Oe Mamba caves, TopaSohi caves, etc. While cultural tourism such as the fortress of Buton kingdom such as the fort Liwuwawono, Fort Pingilai, Fort Lasaidewa, etc.

Nurmalasari (2018) there are three favorite beach tourism potentials in Buton Tengah Regency, namely Katembe beach in Madongka Village, Lakudo District, Wantopi Beach in Wantopi Village, East Mawasangka District, and Mutiara Beach in Gumanano Village, Mawasangka District. These beaches have their own beauty with a variety of uniqueness that differs between one beach with another. 
Mutiara Beach, located in the Gumanano village is a type of beach tourism created due to natural conditions. In addition, the beach has supporting tourism such as cultural tourism BentengLasaidewa, one of the fortresses of Buton Kingdom. In addition, there are also freshwater lakes and saltwater lakes located within close together.

The role of stakeholders in the development of Mutiara beach tourism includes the construction of parking facilities, gazebos, bathrooms, and prayer rooms. The development is considered not optimal, this is supported by the statement of one of the tourists Abdul Azam (2018) who was interviewed by the team (zonasultra.com, 2018) revealed "the beach is very good, many gazebos (rest areas) with a pretty good roof. "Aziz added" unfortunately the condition of the beach is still less attention, that is there is a lot of garbage scattered around the shoreline. Access to the beach is quite tiring because the road is partly unpaved ". This condition is certainly an obstacle for tourists to visit the tourist area.

Wantopi Beach is located in Wantopi village. The beach is a type of beach tourism created by natural conditions. White sand that extends into the bay and almost separated from the mainland. The development of this beach tourism is characterized by the support of the local village government and several community groups that contributed. This can be seen from the construction of bridges and tourist icons and vehicle rides (swings).

On the other hand, in the development process of Wantopi beach tourism is a bit of a problem, such as the problem of handling waste, there is an indirect rejection of some local people towards the process of tourism development. As stated by (Uzi, 2018) states that "the local government is ready to donate hundreds of millions of funds for the development of the tourism object of Wantopi Beach, but people are still reluctant to give Wantopi Beach to be managed by the local government". This situation has resulted in facilities such as bridges and beach icons are worn out and damaged and so far have not been repaired.

Katembe Beach in Madongka Village is a type of beach created by natural conditions. The beach with elongated white sand, with one end bordered by cliffs adds to its uniqueness. The development of the Katembe beach in Madongka Village by the local government is marked by the creation of gazebos (rest area) around the cliffs and beaches, Nurmalasari (2018). In addition, there are also most people who have not yet received tourism development by the government of Buto Tengah Regency. This is indicated by the existence of land donation by the majority of Madongka Village community towards the local government. Another phenomenon is since the leadership of Ir. H. Mansur Amila, M.Tp as the Official (PJ) of Buton Tengah since 2014, until now the leadership of the devinitif Regent $\mathrm{H}$. Samahudin, SE, there is no Regional Regulation (PERDA) about the development and organization of tourism, and so far Government only has the Draft Regional Regulation (RANPERDA) (Sabir, 2018). As a result of the lack of a local regulation governing tourism, tourism development is not optimal. For example there is no regulation between the government and tourism authorities, related to the withdrawal of arbitrary fees. Security for tourists and tourism assets (gazebos and other facilities) is fully carried out on the awareness of tourists and the local community. 
These problems will certainly have an impact on the success of the development of beach tourism. (Antariksa, 2016) argues that several indicators of success in tourism development are tourist security, and tourism management. (Unwto, 2010) added that to create competitive tourism requires attention to several factors including, the level of access, and (Unwto, 2015) fulfillment of environmental needs. (May-Chiun et al, 2013) also added that in maintaining the development of rural tourism, the quality of infrastructure and organizational management is one of the most important.

The description of the background above reveals that the development and policies related to tourism in Buton Tengah are currently not optimal. The statement has been illustrated by the current role of the government which according to researchers is not yet competitive in terms of strategy, and the public does not yet have full awareness of the importance and benefits, as well as their knowledge of tourism. This condition has become the basis of research related to the extent of the current role of stakeholders in the development of beach tourism in Buton Tengah Regency, Southeast Sulawesi Province.The focus of this research is to describe the role of stakeholders in the development of beach tourism in Buton Tengah.Based on the above background, the formulation of this research problem can be described as follows: (1) Why do beach tourism (Mutiara beach, Wantopi beach, and Katembe beach) in Buton Tengah have a low number of visitors and competitiveness? (2) Why does the development of Mutiara, Wantopi, and Katembe beach tourism have low development rates?. Research purposes are (1) Explore Mutiara, Wantopi, and Katembe beach tourism in Buton Tengah; (2) Explore the development of Mutiara, Wantopi, and Katembe beach tourism in Buton Tengah; (3) Finding the appropriate strategy to increase the competitiveness of Mutiara, Wantopi, and Katembe beach tourism in Buton Tengah.

\section{METHODOLOGY}

\section{Research Approaches and Types}

This research is a type of qualitative research by using a case study approach. According to Nugroho (2013) qualitative research is research that is not numerical or not numbers but research that uses sentences or statements. The aim is that a researcher can describe in detail and systematically the situation and phenomena that he wants to study in detail. In this study, the situation and phenomenon that will be discussed is about beach tourism in Buton Tengah Regency.

Research that uses a case study approach according to Yin (2002) is a research method about the social sciences. In addition, Yin also added that case studies are more suitable if the questions in research use how or why, and if a researcher has little opportunity to influence the events to be studied, and the research issues being raised are contemporary (current) issues.

Case study approach is categorized into three types namely Exploratory, Exploratory and Descriptive. This research uses descriptive case study approach which is used to explore a phenomenon that occurs in real life. In this research will reveal certain variables without making comparisons with other variables. 
This research uses a case study approach because the issues raised tend to be social strategies and the issues raised in the research are relatively new. In addition, the researcher does not play an active role in the event/does not have control over the issue being studied.

\section{Research design}

This study uses a Holistic Single Case design. According to Yin (2002) A holistic single case is a study that places the case under study as the focus of research. There are three rational reasons, which are as follows:

1. The first rationale is that a case chosen in the study will be able to become evidence from a well-developed previous theory.

2. Secondary rational, namely a case study that is considered in a research is a unique type of case. These conditions can be circumstances, events or programs that rarely occur or may be the only one.

3. Holistic single case research can be a reason or situation in order to be the start for further research.

\section{The Determination of Research Informants}

In this research, the informants are the stakeholders of beach tourism in Buton Tengah. The stakeholder is chosen because they are the group who knows the situation and has information about the phenomena that will be studied. To find out who is the stakeholder, an identification action is needed to be relevant to the research topic. According to Schiller et al. (2013) there are no systematic techniques and practices for identifying stakeholders. Therefore, a study conducted by previous researchers was limited to personal intuition (decision making based on feelings). This condition made the researcher summarize prospective stakeholders from previous researchers. Kammi (1999)and Schiller et.al. (2013) reveal potential stakeholders including the public sector, policy makers and government, the commercial / private sector, non-governmental organizations, communities, laborers, consumers / tourists, practitioners and professionals, and social and service providers. These potential stakeholders will be used as an initial reference in identifying stakeholders. Then from these potential stakeholders, researcher has summarized a number of stakeholder groups that will be used as potential informants, they are the public sector (Tourism Department, Assembly at Buton Tengah regional), village heads, community representatives, and tourist representatives from each tourist destination.

The number of informants will increase or decrease based on the needs of research data and field conditions when conducting the research. Race \& Millar (2008) this is because not everyone will get the same influence or interest in a policy. In collecting data from informants, researchers will use snowball sampling techniques, so that if there is data that is lacking from one of the stakeholder groups, the researcher can add informants until the researcher gets the information needed.

\section{Research Sites}

The research location is a place where research will be conducted related to cases/issues that will serve as research objects, namely Mutiara beach in Gumano village, Wantopi beach in Wantopi village, and Katembe beach in Madongka village. The reason for determining the location of research is based on several things: 
1. In this area, no research has been conducted on the same problem as this research.

2. Stakeholder research in the area can be used as a reference for beach tourism stakeholders in rural areas horizontally and more specifically on the development of beach tourism in the area where the research is conducted.

3. Three beach tourism in Buton Tengah namely Mutiara beach, Katembe beach, and Wantopi beach) are currently considered to be the priority of the regional government to develop.

4. Currently, the beach tourism is considered to be a favorite beach tourist attraction by tourists/visitors.

\section{Data Sources}

In this research there are two data sources, namely primary and secondary data. Secondary data according to Nugroho (2013) is the use of data directly at the research location by interviewing the main actors in determining policies in-depth, checking between sources and interacting directly into the daily lives of the speakers.

The second data source in this study is secondary data. According to Nugroho (2013) secondary data is the use of data or documents that have been carried out by other researchers.

\section{Data Collection Technique}

The data collection technique in this study is through direct interviews with stakeholders and/or potential stakeholders, documentation and analysis of documents relating to research problems. Instruments of data collection in this study are human, namely "researcher".

\section{Data Analysis}

According to Yin (2011) in analyzing case study data there are five stages of analysis.

1. Data collection, namely the process of summarizing data that has been collected and used as a database.

2. Data reduction, which is the process of simplifying data from the results of accumulation of data that has been collected previously, then sorting or dividing it into more focused parts.

3. Presentation of data, at this stage the researcher will reintegrate the data to become more structured and systematic.

4. Data interpretation, the researcher will present the data. In presenting the data the researcher will rearrange the data, in order to get a new narrative in the study.

\section{Trustworthiness}

In this study, the researcher used four criteria in determining the validity of data, developed by (Nugroho, 2013), they are credibility, transferability, dependability, and conformability.

1. Credibility functions as an Inquiry (looking for answers with scientific questions) so that it can increase the confidence of the research results.

2. Transferability, to meet these criteria, questions need to be asked to the researcher to what extent the research can be applied to other situations until a generalization is reached and shows that the results of the study can apply to other populations. 


\section{Analysis of Tourism Development...}

3. Dependability, this term is the same as reliability which is a requirement in data validity.

4. Conformability, ensuring that the data collected is objective, where there is an agreement between subjects.

\section{FINDING AND DISCUSSION}

Discussion of the data in this study, in addition to using data collected through research findings, also uses data from previous studies or some literature and is certainly relevant to the research of the role of stakeholders in tourism development.

\section{Natural Resources}

Buton Tengah currently has natural and inherited natural resources. Natural resources such as beaches, caves, and lakes. While the inherited natural resources were a legacy of the 16th century Buton kingdom. According to (Dwyer \& Kim, 2003), that the natural resources will affect the framework in which visitors enjoy the destination.

\section{Artificial Resources}

Artificial Resources of beach tourism in Buton Tengah include playgrounds such as swings and canoes provided for tourists who visit. These vehicles were only on Wantopi beach, while in general there are also infrastructures such as shopping places to meet the needs of tourists who are visiting the beach. According to (Dwyer \& Kim, 2003) artificial resources are very important in determining competitiveness.

It means that there are at least five attributes of artificial resources that can affect competitiveness, namely, tourism infrastructure, special events, entertainment, and shopping.

While from the data presented, it was found that artificial tourism in beach tourism destinations in Buton Tengah is currently inadequate.

\section{Tourism Competitiveness}

Accessibility to visit beach tourism in Buton Tengah among others, access to tourist sites was increasingly easy and roads that were under construction. This condition can be seen from the types of transportation that can be used, such as from land mode by motorcycles and cars. Besides that, it can also be accessed by using sea mode, such as speed boat, passenger boat, etc.

Facilities provided by beach tourism in Buton Tengah include gazebos, bathrooms, toilets, and prayer rooms. Facilities certainly become additional products that were needed by tourists at tourist sites. However, not all of these facilities are available in a number of other beach tourism in Buton Tengah. This was caused by tourism management that was not focused on by the local government. The village government itself has tried to carry out development using modest village funds. The local government itself could not work optimally towards the development of Wantopi and Katembe beach tourism, this condition was due to the fact that there has not been an agreement on the granting of the beach location from the community to the local government. 
Precisely, beach tourism in Buton Tengah that has complete facilities was Mutiara beach, because it was managed directly by the local government, compared to Wantopi and Katembe beach tourism which was still managed by the local village government.

Beach tourism attractions in ButonTeng were minimal. In general, Buton Tengah has such competitiveness, but it has not been thoroughly distributed to all of beach tourism. In addition, the attractions carried out on the beach tour are not sustainable. The lack of attraction performed by stakeholders makes tourism monotonous and has no significant competitiveness.

This is due to the lack of stakeholder knowledge of attraction. They only hope that attractions must be carried out by the government, while the government has limited attractions. The government only performs attractions with nuances of commemorating public holidays and so on. In fact, the attractions of beach tourism can utilize a number of cultures and local wisdom. Which Buton Tengah currently has a variety of cultures and local wisdom that can be used to support the competitiveness of tourism, in this case, attractions such as traditional dance, and other cultures.

\section{Organizational Management}

Lack of stakeholder knowledge about the importance of focus on development has made tourism development in Buton Tengah out of control. This condition can be seen from the unsustainable development of tourism inButon Tengah and there was no evaluation of the previous development program. In addition, the Regional Government and Buton Tengah Tourism Office have not yet issued regional regulations related to the management of beach tourism in Buton Tengah up to now.

In addition, the efforts made by the local government to resolve land conflicts that will be used as a tourist location for Wantopi and Katembe beaches have not yielded maximum results. In this case, thelocal governmentcannot bridge the desires of the local community, and the government was also just waiting for a decision from the community regarding the land donation.

This condition invites the researcher to implement a system of focus by external government organizations or Organizational Management, like a private/semi-private organization. According to Dwyer \& Kim (2003) one of the tasks of organization management is Destination Management, which should be carried out by private/semiprivate organizations as an effort to increase the competitiveness of tourist destinations. In addition, Destination Management has responsibilities as destination marketing management, destination planning and development, human resource development, and environmental management.

\section{Communication between Stakeholders}

In general, communication between beach tourism stakeholders in Buton Tengah did not experience obstacles. But specifically, the Wantopi villagers and Madongka villagers, there was a miscommunication with the village government and local government regarding community land donations, which will be used as tourist sites.

Dwyer \& Kim (2003) revealed that one of the tasks of the Destination Organization is the resolution of conflicts that occur between stakeholders. Therefore it is very necessary to 
have a third party, in this case, the Management Organization, both from the government or the private sector, to solve the problem.

\section{Stakeholder Participation}

1) Primary stakeholders, namely the local government (Department of Tourism and Assembly at Buton Tengah regional) were directly involved as the policymakers, were not directly involved in the process of implementing activities and become supervisors of the implementation of activities, and have not been involved in the process of utilizing development results.

2) Primary stakeholders from the village government were involved in every making decision by the local government, and were also directly involved in decision making with village government on tourism development, but on the other hand the village government was not directly involved in the process of implementation, as well as the process of utilizing the results of development.

3) The community itself (villagers) feels that they were always involved in the decisionmaking process by the village government, were involved in the process of carrying out activities both the activities of the village government and the local government, and directly involved in the process of utilizing the results of development.

From the results of the study it was found that the current government has been successful in the process of decision making and implementation of activities, but not in the process of utilizing development results. Utilization of development results is certainly a factor supporting the success of tourism and local revenue, it can also be used to conduct evaluations in order to create more competitive strategies.

At the planning stage, people tried to look to the future and imagine the benefits they will get from a development policy. In this stage, it was necessary to identify what is needed and valued by the community, and include these elements in the image of a policy. This condition helps the community to decide on what development is in accordance with their vision/mission.

\section{The Role of Stakeholders}

1) Primary stakeholders (local government and village government) are responsible in the development of public infrastructure such as opening access roads, and construction of facilities in tourist destination areas such as (gazebos, parking lots, bathrooms, toilets, and Musholla/room prayer) and improving the quality of human resources.

2) The community provides shopping places and participates in protecting the environment, and prepares playgrounds for tourists.

In this case, the researcher was more interested in the development of human resources. As far as this research was concerned the ability of human resources in Buton Tengah was inadequate. Not only the community, but all relevant stakeholders, this statement was known from unsustainable development, and public interest in tourism development was still low.

\section{The Strategies of Competitiveness Improvement}

Beach tourism stakeholders in Buton Tengah feel that the competitiveness it currently has does not support well. They expect the addition of various types of facilities and 
more playgrounds/vehicles, a number of attractions and the promotions from all stakeholders involved in the development of beach tourism in Buton Tengah.

Almost all stakeholders in Buton Tengah expect the availability of attractions could increase tourism competitiveness. Attraction is the type of activity that can be carried out by any group, both from primary stakeholders (government) and secondary stakeholders (community).

The government could create attractions related to the holidays and society also can create attractions that are more structured and sustainable, namely cultural attractions. Buton itself is known have a variety of cultures such as traditional dance, traditional music/songs, traditional food, and other great holidays, which are very unique. This certainly can be an opportunity to improve the competitiveness of tourist destinations and increase regional income and community welfare.

\section{Creating Competitiveness through Several Concepts}

The primary stakeholder (the Tourism Department) of Buton Tengah has collaborated with one of the travel agents in Bau-bau city. It means that this is a good first step to increase the competitiveness of beach tourism in Buton Tengah. The relationship of cooperation between concepts carried out by the local government is currently considered not maximal. However, they could collaborate with other organizations that were affiliatedin tourismassociations such as transportation associations, tour operators, and restaurants, so that these organizations will influence the spread of tourism resources. They may differ in perception about tourism development, but it will be very effective to use if different associations and industry groups have the same point of view in tourism development.

Nevertheless, the condition of the people who refuse to cooperate with the private sector, because of their understanding of the private sector was a company that only looks for profit from the management of tourism. But on the other hand, the author feels that when this condition was explored more deeply it will be opportunities for the government to improve the ability of secondary stakeholders (communities), in order to increase their creativity and ability to manage and utilize tourist destinations in Buton Tengah. It means that if communities were refused the private sector to manage their tourist area, they should be able to become the private sector itself.

From the results of this study, the researcher made a conceptual framework about the role of beach tourism stakeholders in Buton Tengah as follows: 


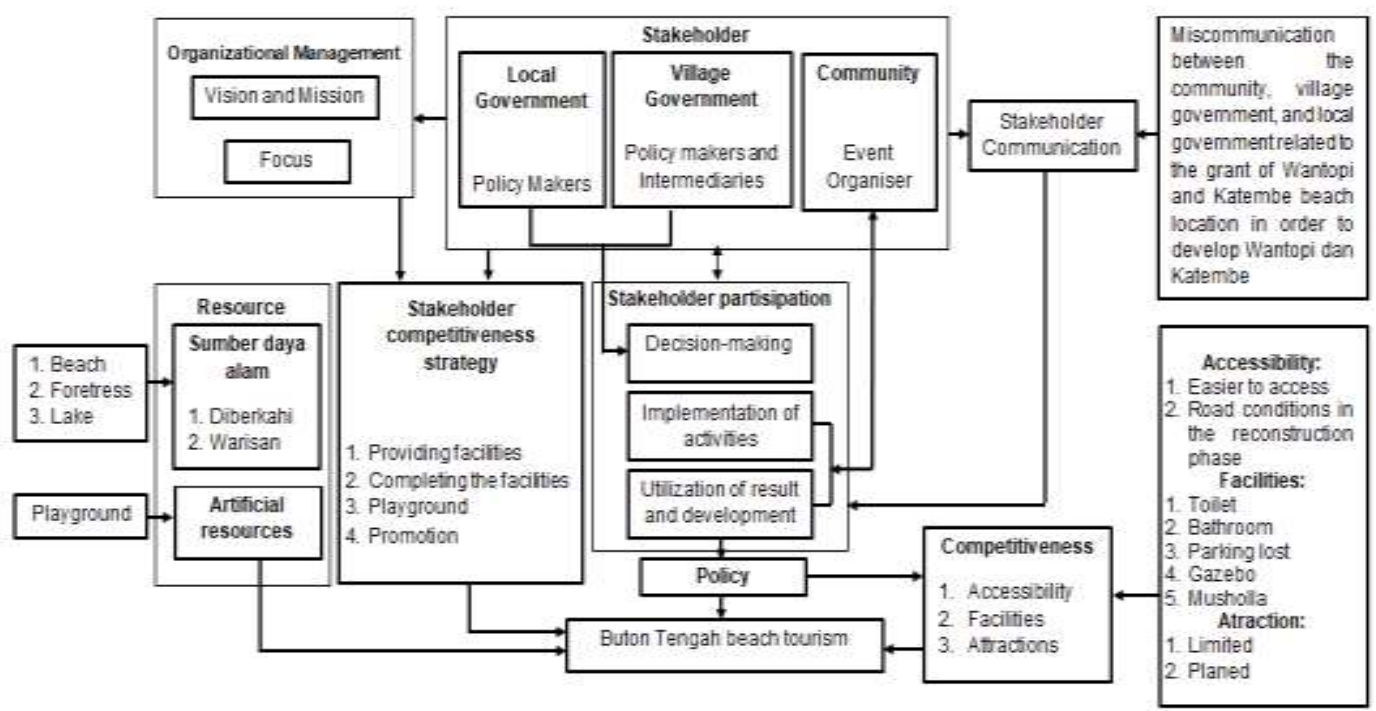

Figure 1. Conceptual framework of the role of beach tourism stakeholders in Buton

Tengah

\section{CONCLUSIONS AND SUGGESTIONS}

\section{Conclusions}

Based on the research problems, research objectives, and research findings, the conclusions of this study are as follows:

From the results of the study, it was found that management of Mutiara beach tourism has been carried out by the local government, while Wantopi beach and Katembe beach tourism was still managed by the village government. Thus, the construction of facilities at these tourist sites by the government has stalled. Besides, the condition of the beach that looks monotonous, so that the beach tourism were only visited by tourists at certain times, namely when holidays and more dominant on traditional ceremonies event.

First, Mutiara beach tourism, although the development of beach location has been managed by the local government, the management of beach tourism was still relatively low. This was because until now there has not been any utilization of the development results obtained by the local government related to the development of beach tourism, and also the local government has not implemented retribution through local regulations on tourism management.

Both Wantopi and Katembe beach tourism, development in these beach locations still relies on village funds, the village government and the community also still expect development to be carried out by the local government. This condition was contradictory to the obligations of local governments, who did not want to build beach tourism as long as the beach location is still not granted to the local government. 
Expected and applicable strategies such as increased construction of facilities in all tourist sites, providing of playgrounds/vehicles, increased promotion, and increased understanding of the community at the beach location about tourism management.

\section{Suggestions}

Based on the research conclusions, the following research suggestions:

The development of beach tourism in Buton Tengah can be done with sustainable development from both local government and the village government, for example by increasing community knowledge about tourism utilization. Besides, the village governments of Wantopi and Katembe can carry out development independently without expecting assistance from local government.

Local government and village government both Wantopi and Katembe villages immediately completed the drafting of regional and village regulations related to the utilization and regulation of beach tourism development. The village governments of Wantopi and Katembe immediately made a settlement related to the grant of beach location, or they could carry out the development independently by using village funds.

Development of facilities by the village and local governments, promotion, creation of attractions by all of the stakeholders, and improvement of human resources related to awareness of tourism development.

\section{REFERENCES}

Antariksa, B. 2017. Kebijakan Pembangunan Sadar Pariwasata: Menuju Daya Saing Kepariwisataan Berkelanjutan. Malang. Intrans Publishing.

Astuti, Reko. E. 2017. Deputi Bidang Pengembangan Pemasaran Pariwisata Nusantara di www.cnnindonesia.com (diaksespada 13 Desember 2018, jam 16:41)

Azam, Abdul. 2018. Wisatawan, Buton Tengah di https://zonasultra.com (diaksespada26 September 2018 Jam 03:42)

Chin, C. H., Thian, S. S. Z., \& Lo, M. C. 2017. Community's experiential knowledge on the development of rural tourism competitive advantage: a study on kampungsemadang - borneo heights, sarawak. Tourism Review. Vol. 72 (2), Pp. 238-260. https://doi.org/10.1108/TR-12-2016-0056

Crosby, B. B. L. 1991. Stakeholder analysis : a vital tool for strategic managers. (2), Pp. 1-6.

Dwyer, L., \& Kim, C. 2003. Destination competitiveness: determinants and indicators. Current Issues in Tourism. Vol. 6(5), Pp. 369-414. https://doi.org/10.1080/13683500308667962 
Hieu, V. U. M., \&Rasovska, I. 2017. Developing cultural tourism upon stakeholders' perceptions toward sustainable tourism development in phuquoclsland, vietnam. Journal of Tourism. Vol. 2(14), Pp. 71-87.

Hugua. 2016. Bupati Wakatobi, di www.cnn indonesia.com (diakses pada 13 Desember 2017, jam 19:02)

Joko Widodo. 2018. Presiden Republik Indonesia, (www.news.detik.comdiakses pada 21 Desember 2018, jam 12:34).

Kammi, S. 1999. Stakeholder analysis guidelines, 2 Analysis Stakeholder. https://doi.org/10.1093/heapol/15.3.338

May-Chiun Lo, Peter Songan, T. Ramayah, AvinW.Yoe, and V. N. 2013. Rural tourism development.industry's perspectives on sustainable tourism. World Applied Sciences Journal. Vol. 65 (3). (SPL.ISS1), 1-5. https://doi.org/10.7763/IPEDR.

Nugroho. Riant. 2013. Metode Penelitian Kebijakan. Yogyakarta: Pustaka Pelajar.

Nurmalasari. Sitti .2018. Reporter, Buton Tengah di https://zonasultra.com (diakses pada 26 September 2018 Jam 03:42)

Race, D., \& Millar, J. 2008. Social and community dimensions to aciar projects. ACIAR Training Manual. Vol. 4 (33).

Sabir, A.2018. Kepala Bagian Hukum Sekretaris Daerah Buton Tengah, di http://butonpos.fajar.co.id (diakses pada 25 November 2018, jam 21:43)

Schiller, C., Winters, M., Hanson, H. M., \& Ashe, M. C. 2013. A framework for stakeholder identification in concept mapping and health research: a novel process and its application to older adult mobility and the built environment. BMC Public Health. Vol. 13 (1), 1-9. https://doi.org/10.1186/1471-2458-13-428

Sotiriadis, M. D. 2014. Culinary tourism assets and events: Suggesting a strategic planning tool. International Journal of Contemporary Hospitality Management. Vol. 27 (6), 1214-1232. https://doi.org/10.1108/IJCHM-11-2013-0519

Tazbir. A. 2012. Kepala Dinas Pariwiata Yogyakarta, Yogyakarta di https://travel.kompas.com (diakses pada 26 September 2018 jam 03:12)

Toader, V., Bota, M., Negrusa, A., Gavriletea, M., \&Tutunea, M. 2013. Networks, Clusters and Innovation in Romanian Tourism. International Journal of Arts \& Sciences. Vol. 6 (2), Pp. 81-89. Retrieved from https://search.proquest.com/docview/1496695659?accountid=14681\%oAhttps://on 
esearch.library.uwa.edu.au/discovery/openurl?institution=61UWA_INST\&vid=61U WA_INST:UWA\&?url_ver=Z39.88-

004\&rft_val_fmt=info:ofi/fmt:kev:mtx:journal\&genre=article\&sid=ProQ:ProQ\%3Aa

Uzi.2018. reporterdi publiksatu.com, Buton Tengah di www.publiksatu.com (diakses pada, 23 November 2018, jam 18:23)

Yin. Robert.K. 2002. Sutdi Kasus: Desain dan Metode. Depok: Raja Grafindo Persada.

Yin, Robert.K. 2011. Case Study Research: DesingAnd Methods. 4 th Edition. New York: SAGE

Žibert, M., Koščak, M., \&Prevolšek, B. 2017. The importance of stakeholder involvement in strategic development of destination management: the case of the mirna valley destination. Academica Turistica. Vol. 10(1), 43-55. https://doi.org/10.26493/23354194.10.43-55 
Analysis of Tourism Development...

58 Management and Economics Journal (MEC-J) Vol 4 (1) April 2020 